\title{
Formulasi dan Karakterisasi SNEDDS Ekstrak Jinten Hitam (Nigella Sativa) dengan Fase Minyak Ikan Hiu Cucut Botol (Centrophorus Sp) serta Uji Aktivitas Imunostimulan
}

\author{
Maya Uzia Beandrade ${ }^{1 *}$ \\ ${ }^{1}$ Sekolah Tinggi Ilmu Kesehatan Mitra Keluarga, Bekasi, Indonesia \\ *email korespondensi : mayauzia@gmail.com
}

Abstrak: Jinten hitam (Nigella sativa) mengandung senyawa timokuinon yang berefek sebagai imunostimulan. Ekstrak jinten hitam dikembangkan menjadi SNEDDS (Self-nanoemulsifying Drug Delivery System) karena masalah kelarutan. Penelitian dilakukan untuk mengetahui karakteristik SNEDDS ekstrak jinten hitam yang meliputi viskositas, ukuran tetesan nanoemulsi, extract loading, dan stabilitas. Pengujian aktivitas imunostimulan SNEDDS meliputi rasio sel makrofag dan indeks fagositosis.

SNEDDS ekstrak jinten hitam dioptimasi dengan metode Simplex Lattice Design menggunakan Design Expert 7.1.5., selanjutnya SNEDDS optimal diuji ukuran tetesan nanoemulsi dan zeta potensial, viskositas, serta uji stabilitas. Uji aktivitas imunostimulan dilakukan dengan metode biolatex assay terhadap tikus Sprague Dawley sebanyak 5 tikus/kelompok selama 15 hari dengan pemberian satu kali sehari yaitu kontrol positif (ekstrak meniran 7,2 mg/tikus), kelompok perlakuan yaitu ekstrak jinten hitam dengan dosis 200 $\mathrm{mg} / \mathrm{kgBB}$ serta SNEDDS ekstrak jinten hitam (200 $\mathrm{mg} / \mathrm{kgBB})$, kelompok plasebo berupa formula SNEDDS tanpa ekstrak jinten hitam, dan kontrol normal, selanjutnya dihitung rasio dan indeks fagositosis makrofag.

SNEDDS ekstrak jinten hitam optimal mengandung 15\% minyak ikan hiu cucut botol, $67,344 \%$ surfaktan $(10,102 \%$ croduret 50 ss dan 57,242\% tween 80), 17,656\% PEG 400 sebagai ko-surfaktan dengan hasil ukuran tetesan nanoemulsi 16,3 nm, PI sebesar 0,202, zeta potensial 43,5 mV, dan viskositas antara 234,69 - 255,71 cP. Hasil extract loading sistem SNEDDS mencapai $600 \mathrm{mg}$ ekstrak/g sistem. SNEDDS stabil setelah penyimpanan selama 90 hari pada suhu kamar dan uji freeze-thawing. SNEDDS ekstrak jinten hitam dengan dosis $200 \mathrm{mg} / \mathrm{kgBB}$ dapat meningkatkan rasio sel makrofag dan indeks fagositosis dibandingkan dengan ekstrak jinten tanpa formulasi $(\mathrm{P}<0,05)$.

Kata kunci : Ekstrak jinten hitam; Simplex Lattice Design; SNEDDS; aktivitas imunostimulan

\begin{abstract}
Optimization of SNEEDS black cumin extract (Nigella Sativa L.) formula with gulper shark liver oil (Centrophorus $S p$ ) and immunostimulant activity study. Black cumin (Nigella sativa) contains timokuinon having immunostimulant effect. However, due to solubility problems, the extract was developed into SNEDDS (Self-nanoemulsifying Drug Delivery System). The study was conducted to find out the characterization of SNEDDS black cumin extract which include viscosity, nanoemulsion droplet size, extract loading and stability. Immunostimulant study was conducted to find out the ratio and phagocytosis index of macrophage.
\end{abstract}


SNEDDS of black cumin extract was optimized using Simplex Lattice Design by Design Expert 7.1.5., The optimal formula then tested the droplet size, zeta potential of nanoemulsion, and viscosity of SNEDDS. Immunostimulant activity test using biolatex assay was carried out on Sprague Dawley rats by 5 mice/group for 15 days by administration once a day, there are a positive control (meniran extract $2,7 \mathrm{mg} / \mathrm{rat}$ ), the treatment group that black cumin extract at dose $200 \mathrm{mg} / \mathrm{kgBW}$ and SNEDDS black cumin extract $(200 \mathrm{mg} / \mathrm{kgBW})$, the placebo group was SNEDDS without black cumin extract, and the last was normal controls, then calculated the ratio of macrophage and phagocytosis index. Furthermore SNEDDS optimal was tested extract loading and stability test.

The optimal formula of SNEDDS black cumin extract containing 15\% Gulper shark liver oil, 67.34\% surfactant (10.10\% Croduret 50 SS and 57.24\% Tween 80), 17.66\% PEG 400 as cosurfactant. The results of the droplet size is $16.3 \mathrm{~nm}$, PI 0.202 , zeta potential $-43.5 \mathrm{mV}$, viscosity of SNEDDS is 234.69 to $255.71 \mathrm{cP}$. SNEDDS black cumin extract $200 \mathrm{mg} / \mathrm{kgBW}$ can increase the ratio of macrophages and phagocytosis index compared with black cumin extract without formulation ( $\mathrm{P}<0.05$ ). SNEDDS system can load up to $600 \mathrm{mg}$ extract/g system. The SNEDDS is stable after storage for 90 days at room temperature and freeze-thawing stability test.

Keywords: Black cumin extract; Simplex Lattice Design; SNEDDS; immunostimulant activity

\section{Pendahuluan}

Sistem kekebalan tubuh perlu dijaga agar terhindar dari berbagai macam penyakit. Jinten hitam (Nigella sativa L.) mengandung timokuinon yang berkhasiat sebagai imunostimulan (Majdalawieh, dkk., 2010; Salem, dkk., 2005). Penelitian Sriningsih and Wibowo (2009) tentang pemberian minyak jinten hitam (Nigella sativa L.) pada tikus dengan dosis $10 \mathrm{mg} / 200 \mathrm{~g} \mathrm{BB} ; 20$ $\mathrm{mg} / 200 \mathrm{~g} \mathrm{BB}$; dan $40 \mathrm{mg} / 200 \mathrm{~g} \mathrm{BB}$ dapat meningkatkan aktivitas makrofag terhadap infeksi bakteri S. epidermidis. Minyak jinten hitam banyak mengandung asam lemak tidak jenuh dimana kelarutan dan bioavailabilitasnya rendah. Permasalahan diatasi dengan formulasi berupa SNEDDS (Self nano-emulsifying drug delivery system) yaitu suatu sistem berupa campuran isotropik antara fase minyak, surfaktan, dan ko-surfaktan yang ketika tercampur dengan air akan membentuk nanoemulsi M/A (minyak dalam air) secara spontan. Nanoemulsi yang terbentuk akan stabil secara termodinamik dengan ukuran droplet pada rentang kurang dari $100 \mathrm{~nm}$ sehingga meningkatkan absorbsi dan bioavailabilitas senyawa herbal (Joshi, dkk., 2013). Optimasi formula ekstrak jinten hitam (Nigella sativa) menjadi SNEDDS (Self nano-emulsifying drug delivery system) dengan metode Simplex Lattice Design menggunakan fase minyak ikan hiu cucut botol (Centrophorus sp) diharapkan akan memperbaiki absorbsi dan bioavailabilitas sehingga akan meningkatkan sistem imun non-spesifik jika dibandingkan dengan ekstrak jinten hitam.

\section{Bahan dan Metode}

\subsection{Bahan}

Biji jinten hitam, propilen glikol, Tween 80, Tween 20, Minyak Ikan Hiu Cucut Botol, Croduret 50 SS (Croda), standar timokuinon (Sigma), tikus putih jantan galur Sprague Dawley (LPPT UGM dengan Ethical Clearance: 330/KEC-LPPT/X/2015), RPMI Medium 1650 powder (Gibco), PBS (Gibco), Fetal Bovine Serum (Biowest), Giemsa (Merck), Latex beads polystirene 3,0 $\mu \mathrm{m}$ (Sigma). 


\subsection{Alat}

Neraca analisis digital (Ohauss PA214), ultrasonicator (J.P. Selecta CY500), magnetic stirrer (Stuart CB162), viskosimeter Brookfield tipe cone and plate, chamber, TLC scanner (Shimadzu), particle size analyzer (Horiba), laminair flow, mikroskop inverted (Olympus).

\subsection{Metode penelitian}

\subsubsection{Determinasi dan karakterisasi ekstrak Jinten Hitam}

Identifikasi dilakukan di Laboratorium Biologi Farmasi Fakultas Farmasi Universitas Gadjah Mada. Ekstrak dibuat dengan cara 2,0 kg biji jinten hitam dimaserasi dengan $12 \mathrm{~L}$ etanol 96\% selama 3 hari. Kemudian ekstrak dikarakterisasi organoleptis meliputi penampilan fisik, warna, dan bau, viskositas ekstrak, dan kadar air ektrak.

\subsubsection{Identifikasi kandungan aktif ekstrak dengan metode KLT densitometri}

Kurva baku dibuat dengan larutan stok timokuinon $0,208 \mathrm{mg} / \mathrm{mL}$, lalu seri larutan baku ditotolkan sebanyak 1, 2, 4, 8, 16, dan $32 \mu \mathrm{L}$. Sampel ditimbang seksama 200,0 mg lalu diekstraksi dengan etanol $96 \%$ p.a hingga 5,0 mL, sampel ditotolkan 5,0 $\mu \mathrm{L}$. Kemudian sampel dielusikan menggunakan fase gerak toluene - etil asetat (98:2), setelah plat KLT dikeringkan lalu diamati pada $\lambda 256 \mathrm{~nm}$.

\subsubsection{Uji kelarutan ekstrak jinten hitam dalam minyak, surfaktan, dan ko-surfaktan}

Uji kelarutan dilakukan dengan 200,0 mg ekstrak jinten hitam dicampur pada 1,0 gram pembawa (minyak ikan hiu cucut botol, Croduret 50 ss, Tween 80, Tween 20, PEG 400 dan Propilen glikol). Supernatan diambil dan diekstraksi dengan alkohol 96\%. Selanjutnya kadar timokuinon diuji dengan KLT densitometri.

\subsubsection{Optimasi dan verifikasi formula SNEDDS dengan Design Expert 7.1.5}

Uji pendahuluan dilakukan secara Trial and Error sehingga diperoleh rentang batas bawah dan batas atas dari Minyak Ikan, Surfaktan, serta Ko-Surfaktan yang menghasilkan transmitan paling tinggi (mendekati 100\%). Selanjutnya dilakukan optimasi formula SNEDDS menggunakan metode Simplex Lattice Design dengan batas atas dan bawah masing-masing komponen yaitu: Variabel A adalah Minyak ikan hiu cucut botol sebesar 15\% - 20\%; Variabel B adalah surfaktan (Croduret 50 SS: Tween $80=15 \%: 85 \%$ ) sebesar $65 \%-70 \%$, dan Variabel C adalah PEG 400 sebesar 15\% - 20\%. Formula SNEDDS optimal diuji kejernihan dengan pengenceran 1:250 dengan metode spektrofotometri pada $\lambda 650 \mathrm{~nm}$. Waktu emulsifikasi dilakukan dengan meneteskan 1,0 ml formula SNEDDS ke dalam $250 \mathrm{ml}$ media Artificial Gastric Fluid ( $\mathrm{NaCl} 500,0 \mathrm{mg}$, HCL 37\% 1,75 mL, lalu ditambahkan akuades hingga 250,0 mL dengan kondisi $\mathrm{pH} 1,2$ ) pada suhu $37^{\circ} \mathrm{C}$ dengan kecepatan $100 \mathrm{rpm}$. Seluruh formula diuji kejernihan dan waktu emulsifikasi sebagai respon yang dimasukkan ke dalam perangkat lunak Design Expert 7.1.5 lalu dianalisis hingga diperoleh formula optimal. Formula optimal yang dipilih adalah yang memiliki nilai desirability paling tinggi (mendekati 1). Kemudian dilakukan 
verifikasi formula optimal untuk membuktikan persentase transmitan dan waktu emulsifikasi hasil prediksi program Design Expert 7.1.5.

\subsubsection{Uji viskositas formula optimal SNEDDS ekstrak Jinten Hitam}

Uji viskositas SNEDDS dilakukan dengan kecepatan spindle 50; 62,5; 75; 87,5; dan 100 rpm pada suhu $25 \pm 1^{\circ} \mathrm{C}$ dengan interval waktu 10 detik (Eid, dkk., 2014).

\subsubsection{Karakterisasi ukuran dan distribusi ukuran tetesan formula optimal SNEDDS}

Sebanyak 100,0 $\mu \mathrm{L}$ formula SNEDDS dengan ekstrak jinten $200 \mathrm{mg} / \mathrm{g}$ dimasukkan ke dalam labu takar $25 \mathrm{~mL}$, ditambahkan akuades hingga tanda, kemudian diukur ukuran partikel dan zeta potensial.

\subsubsection{Uji farmakologi SNEDDS ekstrak Jinten Hitam sebagai imunostimulan}

Tikus galur Sprague-Dawley umur 8 minggu dikelompokkan secara acak. Perlakuan selama 15 hari dengan pemberian 1 kali sehari (Tabel 1). Pada hari ke-15, hewan uji dikorbankan dengan dianestesi menggunakan 10\% ketamine hidroklorida (Ketamil@) dengan dosis 100 $\mathrm{mg} / \mathrm{KgBB}$ tikus melalui injeksi intra muskular, kemudian dikorbankan dengan dislokasi leher. Tikus diletakkan dalam posisi telentang, kulit bagian perut dibuka dan dibersihkan selubung peritoneumnya dengan alkohol $70 \%$, kemudian disuntikkan $10 \mathrm{~mL}$ medium RPMI dingin ke dalam rongga peritoneum, ditunggu selama 3 menit sambil ditepuk-tepuk perlahan. Cairan peritoneum dikeluarkan dari rongga peritoneum kemudian aspirat disentrifus pada $1200 \mathrm{rpm}$, $4^{\circ} \mathrm{C}$ selama 10 menit. Supernatant dibuang, pellet diresuspensi dengan 3,0 mL medium RPMI komplet yang mengandung FBS $10 \%(\mathrm{v} / \mathrm{v})$. Jumlah sel dihitung dengan haemocytometer, kemudian ditambahkan dengan medium komplet sehingga didapatkan suspensi sel dengan kepadatan 2,5 x 10\% $/ \mathrm{ml}$. Suspensi sel ditumbuhkan dalam microcultur $200 \mu \mathrm{L}$ ( 5 x $10^{5} \mathrm{sel}$ ), lalu ditambahkan medium RPMI komplit hingga $1,0 \mathrm{~mL}$. Sel diinkubasi dalam incubator $\mathrm{CO}_{2} 5 \%$, $37^{\circ} \mathrm{C}$ selama 24 jam (Tabel 1 ).

Tabel 1. Pembagian kelompok dan perlakuan hewan uji

\begin{tabular}{cl}
\hline Kelompok & \multicolumn{1}{c}{ Perlakuan } \\
\hline Kelompok 1 & formula SNEDDS jinten hitam dengan dosis ekstrak jinten hitam \\
& 200 mg/Kg BB tikus per oral \\
Kelompok 2 & $\begin{array}{l}\text { Diberi perlakuan dengan dosis ekstrak jinten hitam 200 mg/Kg BB } \\
\text { tikus per oral }\end{array}$ \\
Kelompok 3 & formula SNEDDS tanpa ekstrak jinten hitam (plasebo) per oral \\
Kelompok 4 & Diberi perlakuan ekstrak meniran 2,7 mg/tikus per oral \\
Kelompok 5 & Tanpa perlakuan
\end{tabular}

Partikel lateks diresuspensikan dalam PBS sehingga didapatkan konsentrasi $2,5 \times 10^{7} / \mathrm{mL}$. Makrofag yang telah dikultur sehari sebelumnya dicuci 2 kali dengan medium RPMI, kemudian ditambahkan suspensi lateks $200 \mu \mathrm{L} \quad\left(5 \times 10^{6} / \mathrm{mL}\right)$ pada masing-masing sumuran, lalu diinkubasikan dalam incubator $\mathrm{CO}_{2} 5 \%, 37^{\circ} \mathrm{C}$ selama 60 menit. Sel kemudian dicuci PBS tiga 
kali, dikeringkan pada suhu kamar dan difiksasi dengan methanol absolut selama 30 detik. Setelah sel kering, sel kemudian dipulas dengan giemsa $20 \%$ (v/v). Indeks fagositosis (IF) ditentukan dengan membagi jumlah keseluruhan lateks yang difagositosis oleh 100 sel makrofag terhitung. Rasio fagositosis dihitung dari total sel makrofag aktif dibagi oleh 100 makrofag terhitung kemudian dikalikan 100\% (Santoso, dkk., 2012).

\subsubsection{Uji extract loading formula optimal SNEDDS ekstrak Jinten Hitam}

Uji extract loading dilakukan dengan menambahkan seri bobot ekstrak jinten hitam terhadap formula SNEDDS yaitu 300, 400, 500, 600, 700, dan 800 mg/g sistem. Formula SNEDDS yang mampu menampung ekstrak jinten hitam paling banyak apabila memberikan penampilan visual yang masih jernih dan waktu emulsifikasi kurang dari 1 menit.

\subsubsection{Uji stabilitas SNEDDS ekstrak Jinten Hitam}

Uji penyimpanan pada suhu ruang selama 90 hari : SNEDDS disimpan pada suhu ruang $\left(25^{\circ} \mathrm{C}\right)$ selama 90 hari. Kemudian diamati jika terjadi perubahan fisik, bau, warna pada sediaan SNEDDS ekstrak jinten hitam. Persentase transmitan dan waktu emulsifikasi diuji sebelum dan setelah perlakuan.

Uji freeze-thawing : SNEDDS disimpan pada suhu $-21^{\circ} \mathrm{C}$ selama 24 jam kemudian disimpan pada suhu ruang $25^{\circ} \mathrm{C}$ selama 24 jam (satu siklus). Proses ini diulang hingga 6 siklus, lalu diamati perubahan fisik, warna, dan bau. Uji kejernihan dan waktu emulsifikasi dilakukan sebelum dan setelah perlakuan.

\section{Hasil dan Pembahasan}

\subsection{Determinasi biji Jinten Hitam dan karakterisasi ekstrak Jinten Hitam}

Hasil determinasi menyatakan bahwa sampel yang digunakan adalah benar yaitu merupakan suku tanaman Ranunculaceae dengan jenis Nigella sativa L. Rendemen yang diperoleh dari hasil penelitian adalah sebesar 25,34\%. Hasil karakterisasi ekstrak jinten hitam. (Tabel 2). Kadar air ekstrak jinten hitam hasil penelitian diperoleh rata-rata 1,00\% Berdasarkan Materia Medika Indonesia Jilid I, persyaratan kadar air adalah kurang dari 10,00 \% (RI., 2009) Asam lemak utama dalam minyak jinten hitam adalah asam lemak tidak jenuh sebesar 85,75\% b/v (Gharby, dkk., 2013).

\subsection{Uji kelarutan ekstrak Jinten Hitam dalam minyak, surfaktan, dan ko-surfaktan}

Pada gambar 1 terlihat bahwa kelarutan timokuinon pada ekstrak jinten hitam tergolong tinggi dalam minyak ikan hiu cucut botol karena memiliki kemiripan kandungan utama asam lemak dalam komponennya yaitu sebagian besar merupakan asam oleat. Kelarutan timokuinon dalam surfaktan yaitu Tween 80 adalah 1,63 $\pm 0,01 \%$ b/b dengan nilai RSD sebesar 0,81\%, kelarutan timokuinon dalam Croduret 50 ss adalah sebesar $0,81 \pm 0,01 \%$ b/b dengan nilai RSD sebesar 1,63\%, kemudian kelarutan timokuinon dalam Tween 20 diperoleh paling kecil diantara jenis surfaktan lainnya yaitu sebesar $0,78 \pm 0,023 \%$ b/b dengan nilai RSD sebesar 3,38\%. Kelarutan timokuinon dalam ko-surfaktan PEG 400 lebih tinggi daripada dalam propilen glikol 
yaitu sebesar $1,29 \pm 0,05 \%$ b/b dengan nilai RSD sebesar 3,93\%, sedangkan kelarutan timokuinon dalam propilen glikol adalah sebesar $0,99 \pm 0,02 \%$ b/b dengan nilai RSD sebesar 2,13\%.

Tabel 2. Karakterisasi ekstrak jinten hitam

\begin{tabular}{lc}
\hline \multicolumn{1}{c}{ Karakterisasi } & Hasil \\
\hline Penampilan fisik, warna, bau & Minyak, warna kuning kecoklatan, bau khas atsiri \\
Viskositas & $19,32-21,76 \mathrm{cP}$ \\
Kadar air & $1,00 \%$ \\
Asam lemak jenuh & $13,66 \% \mathrm{~b} / \mathrm{v}$ \\
Asam lemak tidak jenuh & $85,75 \% \mathrm{~b} / \mathrm{v}$ \\
\hline
\end{tabular}

\subsection{Desain formula SNEDDS ekstrak Jinten Hitam dengan Design Expert 7.1.5}

Batas atas dan batas bawah masing-masing komponen minyak, surfaktan, dan ko-surfaktan diperoleh berdasarkan percobaan pendahuluan yang dapat dilihat pada tabel 3. Kombinasi surfaktan antara Croduret 50 SS (Polyoxyl 50 Hydrogenated Castor Oil) dan Tween 80 dilakukan karena dapat meningkatkan efisiensi emulsifikasi dari sistem nanoemulsi (Ishah, dkk., 2011).

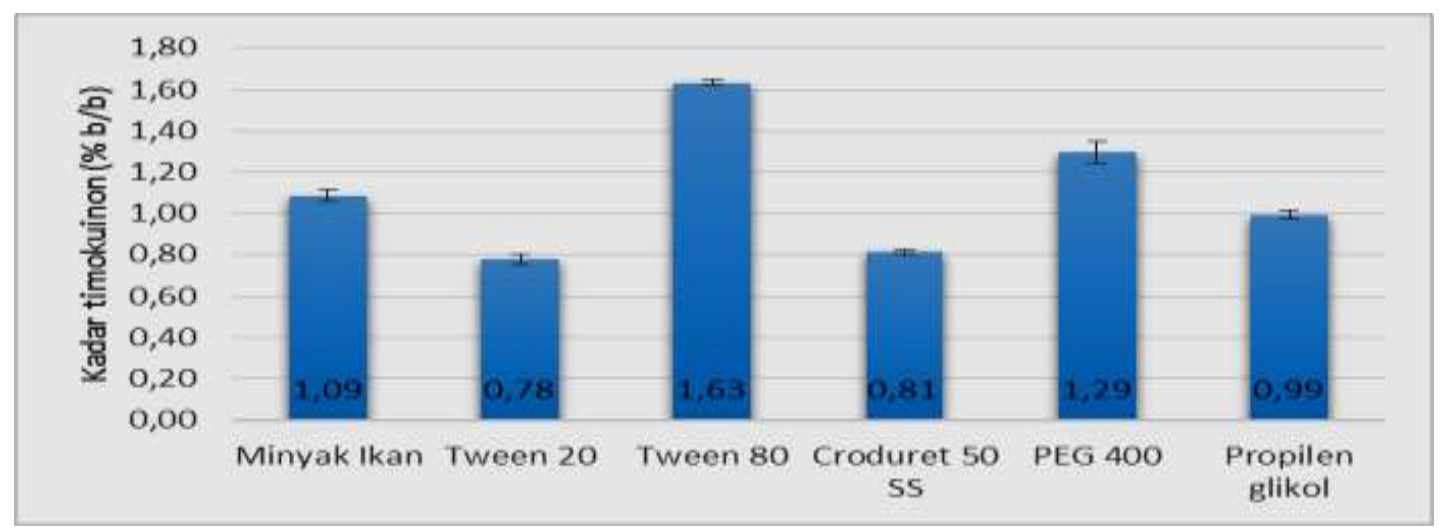

Gambar 1. Kelarutan timokuinon dalam minyak, surfaktan, dan ko-surfaktan

Tabel 3. Batas bawah dan atas komponen SNEDDS

\begin{tabular}{lcc}
\hline Komponen SNEDDS & Batas bawah & Batas atas \\
\hline Minyak ikan hiu cucut botol & $15 \%$ & $20 \%$ \\
Surfaktan & $65 \%$ & $70 \%$ \\
(Croduret 50 SS: Tween $80=15 \%: 85 \%)$ & $15 \%$ & $20 \%$ \\
PEG 400 & & \\
\hline
\end{tabular}

Pengaruh positif (meningkatkan persentase transmitan) diberikan oleh komponen minyak (A), surfaktan (B), minyak dan ko-surfaktan (BC), dan surfaktan-ko-surfaktan (AC), sedangkan pengaruh negatif (menurunkan persentase transmitan) terlihat pada komponen ko-surfaktan (C) dan interaksi antara minyak dan surfaktan (AB). Minyak dan surfaktan lebih mempengaruhi persentase transmitan dibandingkan pengaruh komponen minyak-ko-surfaktan dan surfaktan-kosurfaktan, padahal seharusnya peningkatan minyak dapat menurunkan persentase transmitan yang mengindikasikan terjadi peningkatan ukuran tetesan nanoemulsi. Hal ini kemungkinan 
dapat terjadi karena minyak ikan hiu cucut botol mampu melarutkan ekstrak jinten hitam dengan baik sehingga mempengaruhi pembentukan ukuran nanoemulsi dengan optimal yang menyebabkan persentase transmitan semakin tinggi. Komponen surfaktan juga dapat meningkatkan persentase transmitan, hal ini karena fungsi utama dari surfaktan adalah menurunkan tegangan permukaan antara fase minyak dan air sehingga dapat diperoleh ukuran tetesan nanoemulsi semakin kecil. Ko-surfaktan ternyata dapat menurunkan persentase transmitan jika melihat dari pengaruh negatif yang dihasilkan, walaupun pengaruhnya lebih kecil dibandingkan komponen minyak atau surfaktan. Pada penelitian diperoleh hasil bahwa komponen ko-surfaktan dapat memperbesar ukuran tetesan nanoemulsi karena dapat memperbesar lapisan film antara minyak dan air. Pengaruh komponen minyak-surfaktan juga memberikan interaksi negatif pada kejernihan nanoemulsi walaupun pengaruhnya tidak sebesar komponen ko-surfaktan.

Tabel 4. Analisa komposisi optimum berdasarkan SLD [response variable]

\begin{tabular}{llc}
\hline \multicolumn{1}{c}{ Respon Variabel } & \multicolumn{1}{c}{ Persamaan Matematika } & Model Matematika \\
\hline \multirow{2}{*}{ Transmitan [\%] } & $\mathrm{Y}=5,92209 \mathrm{~A}+1,4706 \mathrm{~B}-$ & \\
& $1,25936 \mathrm{C}-0,092190 \mathrm{AB}+$ & \\
& $0,021527 \mathrm{AC}+0,016955 \mathrm{BC}$ & \\
& & \\
& $\mathrm{Y}=9541,17709 \mathrm{~A}+959,4358 \mathrm{~B}+$ & \\
Waktu emulsi [detik] & $9200,31357 \mathrm{C}-173,36854 \mathrm{AB}-$ & \\
& $691,90991 \mathrm{AC}-168,44272 \mathrm{BC}+$ & \\
& $10,57083 \mathrm{ABC}$ & \\
& & \\
\hline
\end{tabular}

Komponen yang akan dioptimasi adalah minyak, surfaktan, dan ko-surfaktan. Pembobotan ini disebut juga importance, di mana terdapat pilihan tanda positif satu (+) hingga tanda positif lima (+++++). Semakin tinggi tingkat kepentingan dari komponen dan respon yang diukur, maka semakin besar bobot kepentingan yang diberikan. Bobot kepentingan dan target respon formula SNEDDS dapat dilihat pada tabel 4. Komponen minyak (15-20\%), surfaktan (65-70\%), dan kosurfaktan (15-20\%) dioptimalkan dengan target komponen in range dan importance sebesar tiga $(+++)$. Hal ini dikarenakan pada rentang tersebut, komponen minyak, surfaktan, dan ko-surfaktan masih memenuhi persyaratan SNEDDS dalam membentuk nanoemulsi spontan. Respon persentase transmitan diberikan bobot kepentingan tiga (+++) dengan target maximize yang berarti formula optimal diinginkan untuk diperoleh respon transmitan paling tinggi. Bobot kepentingan diberikan nilai tiga karena nilai persentase transmitan hasil percobaan telah memenuhi persyaratan yaitu $>90 \%$ yang berarti telah diperoleh nanoemulsi yang jernih (Sagar, dkk., 2014). Respon waktu emulsifikasi diberikan bobot kepentingan lima (+++++) dengan target minimize yang berarti formula diinginkan dapat memberikan waktu emulsifikasi spontan yang paling singkat. Bobot kepentingan untuk respon emulsifikasi diberikan paling besar di antara yang lain karena pada hasil respon sebelumnya diperoleh waktu emulsifikasi yang tinggi hingga mencapai 195 detik, padahal persyaratan emulsifikasi spontan sediaan SNEDDS adalah kurang dari 60 detik (Engelen, dkk., 2015). Formula yang disarankan oleh program Design Expert 7.1.5 sebanyak 3 solusi seperti yang terlihat pada tabel 5. 
Solusi yang dipilih adalah formula pertama karena memberikan angka desirability paling tinggi yang mendekati nilai 1,000. Formula optimal yang disarankan memiliki komposisi minyak sebesar $15 \%$, surfaktan sebesar $67,344 \%$, dan ko-surfaktan sebesar 17,656\%. Formula ini diprediksi akan memberikan hasil persentase transmitan sebesar 98,3713 \%, dan prediksi waktu emulsifikasi sebesar 47,3524 detik. Nilai desirability dari formula optimal ini adalah sebesar 0,768 yang berarti formula tersebut akan menghasilkan karakteristik paling optimal dan sesuai dengan keinginan peneliti sebesar 76,8\% (Gambar 2). Pada point prediction dari program Design Expert 7.1.5 terdapat perkiraan nilai respon hasil observasi dengan taraf kepercayaan $95 \%$ (tabel 6). Proses verifikasi ini dengan melihat apakah nilai hasil observasi kita berada pada rentang Confidence Interval (CI) dan Prediction Interval (PI). 95\% CI (confidence interval) adalah rentang nilai rata-rata hasil observasi pada taraf kepercayaan 95\%, sedangkan 95\% PI (prediction interval) adalah rentang nilai prediksi individu hasil observasi pada taraf kepercayaan $95 \%$. Rentang nilai PI lebih besar daripada CI karena nilai individu hasil observasi pasti lebih bervariasi dibandingkan nilai rata-rata hasil observasi (Englen, dkk., 2015; Purnomo, dkk., 2012). Keseluruhan respon observasi persentase transmitan dan waktu emulsifikasi masuk pada rentang CI dan PI dari Design Expert 7.1.5.

Tabel 5. Optimasi formula SNEDDS ekstrak jinten hitam

\begin{tabular}{lcccc}
\hline \multicolumn{1}{c}{ Nama } & Target & Lower limit & Upper limit & Importance \\
\hline Minyak & is in range & 15 & 20 & 3 \\
Surfaktan & is in range & 65 & 70 & 3 \\
Ko-surfaktan & is in range & 15 & 20 & 3 \\
Transmitan & maximize & 97,8 & 98,8 & 3 \\
Waktu emulsifikasi & minimize & 34 & 195 & 5 \\
\hline
\end{tabular}

Tabel 6. Solusi formula optimal SNEDDS berdasarkan Design Expert 7.1.5

\begin{tabular}{ccccccc}
\hline No & $\begin{array}{c}\text { Minyak } \\
(\boldsymbol{\%})\end{array}$ & $\begin{array}{c}\text { Surfaktan } \\
(\boldsymbol{\%})\end{array}$ & $\begin{array}{c}\text { Kosurfa } \\
\text { ktan(\%) }\end{array}$ & $\begin{array}{c}\text { Transmitan } \\
(\boldsymbol{\%})\end{array}$ & $\begin{array}{c}\text { Waktu } \\
\text { emulsifikasi } \\
(\text { detik) }\end{array}$ & Desirability \\
\hline 1 & 15,000 & 67,344 & 17,656 & 98,3713 & 47,3524 & 0,768 \\
2 & 17,385 & 65,000 & 17,615 & 98,1938 & 54,9747 & 0,646 \\
3 & 16,334 & 68,666 & 15,000 & 98,1645 & 105,399 & 0,475 \\
\hline
\end{tabular}

\subsection{Uji viskositas formula optimal SNEDDS ekstrak Jinten Hitam}

Berdasarkan hasil percobaan diperoleh hasil viskositas SNEDDS ekstrak jinten optimal antara 238,92 - 251,36 cP (Gambar 3) sehingga akan mudah difilling ke dalam kapsul gelatin lunak atau keras karena viskositasnya kurang dari 10,000 cP (Belhadj, dkk., 2013).

\subsection{Karakterisasi ukuran dan zeta potensial tetesan formula optimal SNEDDS}

Ukuran tetesan nanoemulsi sebesar 16,3 $\mathrm{nm}$ dengan nilai polydispersity index (PI) sebesar 0,202 sehingga distribusi ukuran partikelnya dinyatakan seragam (Balakumar, dkk., 2013; Einien, dkk., 2012). Ukuran tetesan nanoemulsi yang lebih kecil daripada kapiler darah (400 nm) dapat diabsorbsi lebih baik dan meminimalkan kemungkinan kapiler darah menghalangi proses 
transport tetesan nanoemulsi dan distribusi ukuran partikel yang seragam menyebabkan zat aktif dapat diabsorbsi dengan kecepatan relatif sama dan cepat sehingga meningkatkan bioavailabilitasnya (Kumar, dkk., 2013). Hasil zeta potensial nanoemulsi adalah sebesar -43,5 $\mathrm{mV}$ sehingga tidak terjadi flokulasi. Nilai zeta potensial yang lebih dari $\pm 30 \mathrm{mV}$ memberikan kestabilan tetesan nanoemulsi pada sistem sehingga tidak terjadi flokulasi (Balakumar, dkk., 2013). Muatan negatif dari permukaan tetesan nanoemulsi terjadi akibat adanya asam lemak bebas yang berasal dari komponen SNEDDS yaitu minyak, surfaktan, ko-surfaktan, serta ekstrak jinten hitam yang mengandung asam lemak.

Tabel 7. Prediksi dan hasil verifikasi respon formula optimal SNEDDS.

\begin{tabular}{|c|c|c|c|c|c|c|}
\hline \multirow[t]{2}{*}{ Respon } & \multirow[t]{2}{*}{ Prediksi } & \multirow[t]{2}{*}{ Observasi } & \multicolumn{2}{|c|}{$95 \% \mathrm{CI}$} & \multicolumn{2}{|c|}{ 95\% PI } \\
\hline & & & Low & High & Low & High \\
\hline \multirow{3}{*}{$\begin{array}{c}\text { Transmitan } \\
(\%)\end{array}$} & \multirow{3}{*}{98,37} & 98,00 & \multirow{3}{*}{98,02} & \multirow{3}{*}{98,73} & \multirow{3}{*}{97,82} & \multirow{3}{*}{98,92} \\
\hline & & 98,20 & & & & \\
\hline & & 98,30 & & & & \\
\hline Rata-rata \pm SD & & $98,17 \pm 0,15$ & & & & \\
\hline \multirow{3}{*}{$\begin{array}{c}\text { Waktu } \\
\text { emulsifikasi } \\
\text { (detik) }\end{array}$} & \multirow{3}{*}{47,35} & 50,02 & \multirow{3}{*}{39,06} & \multirow{3}{*}{55,73} & \multirow{3}{*}{35,32} & \multirow{3}{*}{59,47} \\
\hline & & 49,24 & & & & \\
\hline & & 49,29 & & & & \\
\hline Rata-rata \pm SD & & $49,52 \pm 0,44$ & & & & \\
\hline
\end{tabular}

\subsection{Uji farmakologi SNEDDS ekstrak Jinten Hitam sebagai imunostimulan}

Pada penelitian dilakukan uji imunostimulan dengan biolatex assay menggunakan hewan uji tikus Sprague-Dawley. Hasil uji rasio sel makrofag dapat dilihat pada gambar 2. Hasil Kruskal-Wallis Test menunjukkan data rasio sel makrofag antar kelompok perlakukan berbeda secara signifikan yaitu 0,001 sehingga dilanjutkan uji Mann-Whitney untuk melihat perbedaan antar kelompok. Berdasarkan analisis statistik diperoleh hasil bahwa SNEDDS ekstrak jinten hitam $200 \mathrm{mg} / \mathrm{kgBB}$ memberikan hasil rasio sel makrofag paling tinggi diantara kelompok perlakuan yang lain yaitu sebesar 95,2 $\pm 1,17 \%$ ( $\mathrm{p}<0,05)$. Indeks fagositosis adalah kemampuan sel makrofag aktif dalam memfagositosis lateks, semakin banyak lateks yang difagositosis maka kapasitas fagositosisnya semakin tinggi (Gambar 3).

Hasil Kruskal-Wallis Test menunjukkan data indeks fagositosis antar kelompok perlakukan berbeda secara signifikan yaitu 0,001 sehingga dilanjutkan uji Mann-Whitney untuk melihat perbedaan antar kelompok. Berdasarkan hasil analisis statistik, diperoleh hasil bahwa SNEDDS yang mengandung ekstrak jinten hitam dapat meningkatkan indeks fagositosis makrofag apabila dibandingkan dengan ekstrak jinten tanpa formulasi $(\mathrm{p}<0,05)$ dengan nilai $4,03 \pm 0,70$. Ketika ekstrak jinten hitam diformulasi menjadi SNEDDS dengan komposisi minyak ikan hiu cucut botol, surfaktan (Croduret 50 ss dan Tween 80), dengan ko-surfaktan PEG 400 ternyata efek imunostimulan lebih tinggi dibandingkan dengan ekstrak jinten tanpa formulasi, bahkan diperoleh hasil dapat meningkatkan rasio makrofag aktif lebih tinggi dibandingkan kontrol positif meskipun hasil indeks fagositosisnya tidak berbeda secara signifikan. Hal ini dipengaruhi oleh formula dari SNEDDS minyak jinten hitam yaitu minyak ikan hiu cucut botol yang merupakan trigliserida rantai panjang, dapat berfungsi untuk melarutkan ekstrak jinten hitam 
yang berupa minyak dengan lipofilisitas yang tinggi. Selain itu penggunaan minyak rantai panjang adalah sifatnya yang lipofil (log P>5) sehingga proses absorbsinya akan melalui jalur limfatik sehingga terhindar dari metabolisme hati dan meminimalkan efek hepatotoksik (Li, dkk., 2011).

Surfaktan yang merupakan komponen formula SNEDDS dapat meningkatkan permeabilitas membran dengan merusak lapisan lipid bilayer dari sel epitel. Monomer surfaktan dapat melekatkan molekulnya pada membran sel epitel sehingga memberikan efek lebih polar pada membran lipid. Surfaktan juga dapat berperan dalam membuka tight junction antar sel epitel dengan cara interaksi dengan bagian polar dari lipid bilayer, memodifikasi ikatan hidrogen dan ionik antar grup, sekaligus dapat memasukkan molekul lipofilnya pada bilayer sehingga membran sel terbuka (Li, dkk., 2011). Selain itu komponen surfaktan pada SNEDDS yaitu Croduret 50 ss dan tween 80 dapat meningkatkan absorbsi karena memiliki kemampuan menghambat transport efluks p-glikoprotein yaitu suatu protein yang dapat mengeluarkan obat setelah diabsorbsi, dapat menghambat enzim sitokrom untuk metabolisme obat, serta memiliki karakter untuk diabsorbsi melalui limfatik sehingga beberapa mekanisme ini juga dapat meningkatkan bioavailabilitas dari minyak jinten hitam yang berefek imunostimulan (Avacat, dkk., 2015).

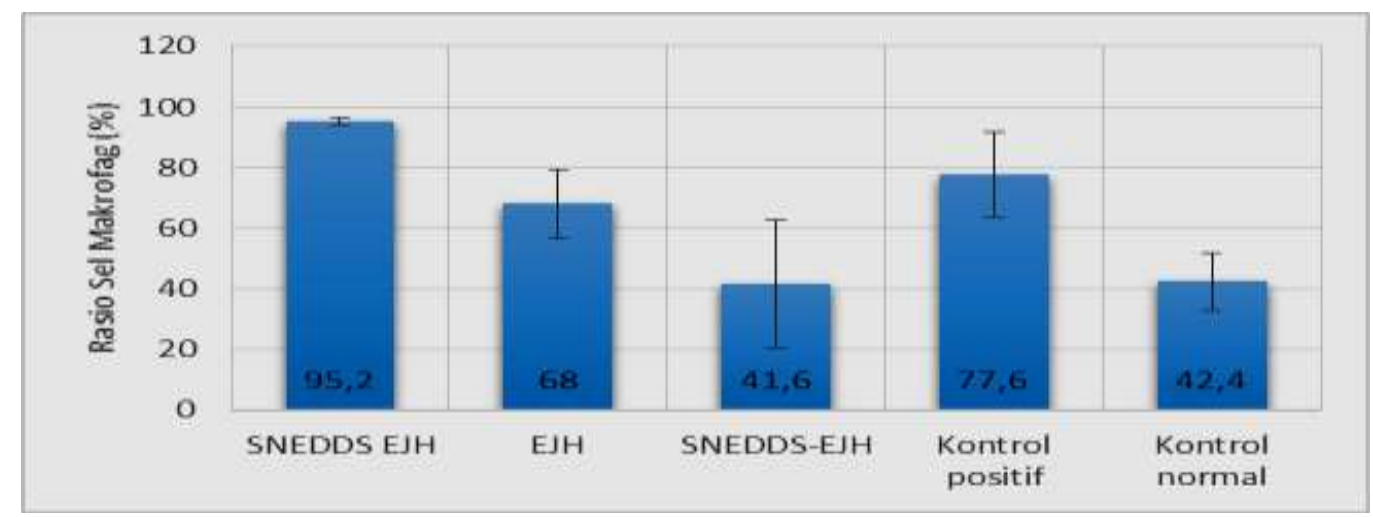

Gambar 2. Rasio sel makrofag (\%)

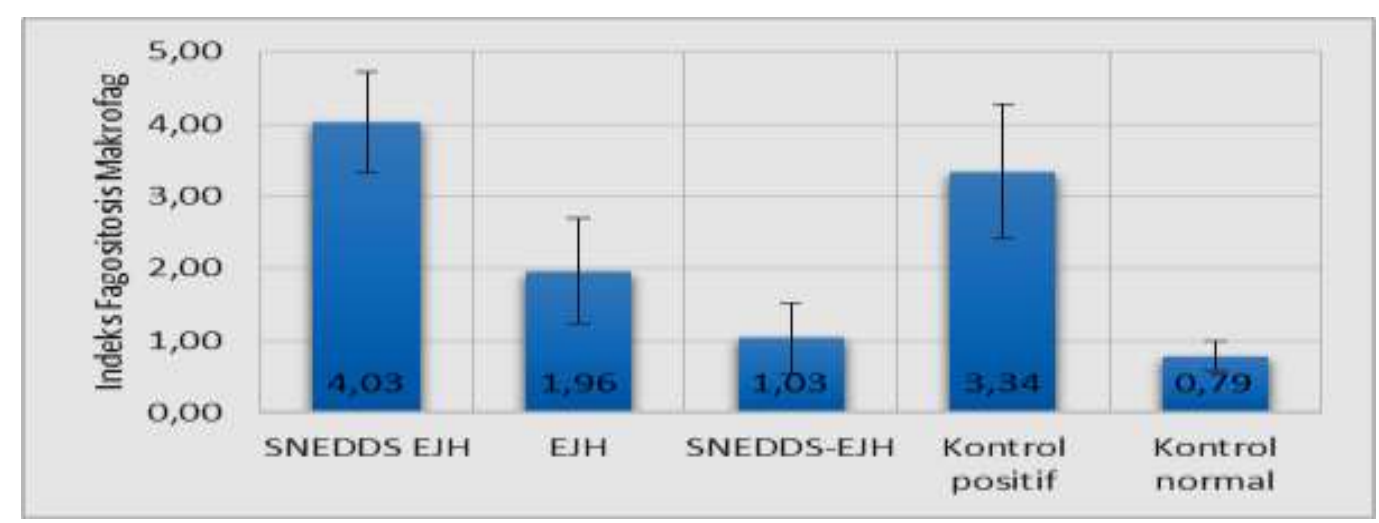

Gambar 3. Indeks fagositosis makrofag

\subsection{Uji extract loading formula SNEDDS ekstrak Jinten Hitam optimal}

Sistem SNEDDS mampu memuat ekstrak jinten hitam menjadi 3 kali lipat dari formula optimal yaitu dari dosis $200 \mathrm{mg} / \mathrm{g}$ menjadi $600 \mathrm{mg} / \mathrm{g}$ sistem SNEDDS dengan nilai persentase

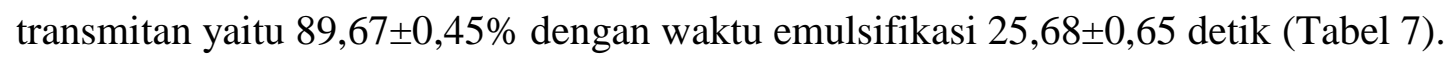




\subsection{Uji stabilitas termodinamika SNEDDS}

Hasil uji stabilitas selama 90 hari pada dosis ekstrak $200 \mathrm{mg}$, $500 \mathrm{mg}$, dan $600 \mathrm{mg} / \mathrm{g}$ sistem SNEDDS memberikan hasil yaitu penampilan visualnya tetap jernih dan tidak terjadi pemisahan fase. Uji kejernihan serta waktu emulsifikasi sebelum dan setelah penyimpanan ternyata tidak memberikan perbedaan signifikan secara statistik ( $p>0,05)$. Hasil uji stabilitas dengan metode freeze-thaw dengan uji kejernihan serta uji waktu emulsifikasi sebelum dan setelah penyimpanan ternyata tidak memberikan perbedaan signifikan secara statistik $(\mathrm{p}>0,05)$.

\section{Kesimpulan}

Berdasarkan hasil penelitian diperoleh SNEDDS optimal mengandung ekstrak jinten hitam $200 \mathrm{mg} / \mathrm{g}$ sistem. Sistem SNEDDS terdiri dari minyak ikan hiu cucut botol sebesar 15\%, surfaktan sebesar $67,34 \%$ yang mengandung Croduret 50 ss sebesar $10,10 \%$ dan Tween 80 sebesar 57,24\%, serta ko-surfaktan PEG 400 sebesar 17,66\%. SNEDDS optimal memiliki karakterisitik viskositas kurang dari 10,000 cP, ukuran nanoemulsi sebesar 16,3 nm dengan indeks polidispersitas (PI) 0,202, dan zeta potensial $-43,5 \mathrm{mV}$. Formula optimal SNEDDS ekstrak jinten hitam dengan dosis $200 \mathrm{mg} / \mathrm{kgBB}$ memberikan hasil rasio sel makrofag dan indeks fagositosis lebih tinggi apabila dibandingkan dengan ekstrak jinten hitam tanpa formulasi ( $\mathrm{p}<0,05$ ). Formula optimal SNEDDS mampu menampung hingga $600 \mathrm{mg}$ ekstrak dan stabil ketika disimpan selama 90 hari pada suhu ruang serta stabil ketika diuji stabilitas dengan teknik freeze-thawing.

\section{Daftar Pustaka}

Ali, A., Muhee, H. \& Al-Leban, W. S. Black Cumin (Nigella sativa L.) Affects Some Parameter in Male Albino Rats. Int. J. Med. Pharm. Sci. 4, 59-68 (2014).

Avachat, A. M. \& Patel, V. G. Self nanoemulsifying drug delivery system of stabilized ellagic acid-phospholipid complex with improved dissolution and permeability. Saudi Pharm. J. 23, 276-289 (2015).

Balakumar, K., Raghavan, C. V., selvan, N. T., prasad, R. H. \& Abdu, S. Self nanoemulsifying drug delivery system (SNEDDS) of Rosuvastatin calcium: Design, formulation, bioavailability and pharmacokinetic evaluation. Colloids Surfaces B Biointerfaces 112, 337-343 (2013).

Belhadj, Z., Zhang, S., Zhang, W. \& Wang, J. Formulation Development and Bioavailability Evaluation of a Self-nanoemulsifying Drug Delivery System ( SNEDDS ) of Atorvastatin Calcium. Int. J. Pharm. 29, 1103-1113 (2013).

Eid, A. M., El-Enshasy, H. A., Aziz, R. \& Elmarzugi, N. A. The preparation and evaluation of self-nanoemulsifying systems containing swietenia oil and an examination of its antiinflammatory effects. Int. J. Nanomedicine 9, 4685-4695 (2014).

Einien, M. A., El Mahrouk, G. \& Elkasabgy, N. Design and In-Vitro Evaluation of OlanzapineLoaded Self Nanoemulsifying Drug Delivery System. Int. J. Institutional Pharm. Life Sci. 2, 12-32 (2012).

Engelen, A., Sugiyono \& Budijanto, S. Optimasi Proses Dan Formula Pada Pengolahan Mi Sagu Kering. AGRITECH 35, 359-367 (2015).

Gharby, S. et al. Chemical Investigation of Nigella sativa L. Seed Oil Produced in Morocco. J. Saudi Soc. Agric. Sci. 14, 172-177 (2013). 
Ishan, S. Development and Characterization of Oil-in-Water Nanoemulsions from SelfMicroemulsifying Mixtures. (2011).

Joshi, R. P. et al. SNEDDS curcumin formulation leads to enhanced protection from pain and functional deficits associated with diabetic neuropathy: An insight into its mechanism for neuroprotection. Nanomedicine Nanotechnology, Biol. Med. 9, 776-785 (2013).

Kumar, R. S. et al. Self nanoemulsifying drug delivery system of olanzapine for enhanced oral bioavailability: in vitro, in vivo characterization and in vitro-in vivo correlation. $J$ Bioequivalence Bioavailab 5, 201-208 (2013).

Li, W. et al. Self-nanoemulsifying drug delivery system of persimmon leaf extract: Optimization and bioavailability studies. Int. J. Pharm. 420, 161-171 (2011).

Majdalawieh, A. F., Hmaidan, R. \& Carr, R. I. Nigella sativa modulates splenocyte proliferation, Th1/Th2 cytokine profile, macrophage function and NK anti-tumor activity. $J$. Ethnopharmacol. 131, 268-275 (2010).

Purnomo, E. H., Sitanggang, A. B., Agustin, D. S., Hariyadi, P. \& Hartono, S. Formulation and Process Optimization of Muffin Produced From Composite Flour of Corn, Wheat and Sweet Potato. J. Teknol dan Ind. Pangan 23, 165-172 (2012).

RI, D. Materia Medika Indonesia. (2009).

Sagar, K., Kendre, P., Pande, V. \& Chaundhari, V. Design, Development, and Characterization of Self Nanoemulsifying Drug Delivery System (SNEDDS) of Nateglinide. World J. Pharm. Pharm. Sci. 3, 794-811 (2014).

Salem, M. L. Immunomodulatory and therapeutic properties of the Nigella sativa L. seed. Int. Immunopharmacol. 5, 1749-1770 (2005).

Santoso, M. A. A., Handajani, J. \& Jonarta, A. L. Effect of the Exposure Time of 0, 01\% Blackseed (Nigella sativa Linn.) Volatile Oil on The Phagocytic Activity of Macrophage Cells in vitro. Indones. J. Dent. Res. 119-131 (2012).

Sriningsih \& Wibowo, A. E. Efek Imunostimulan Ekstrak Meniran (Phyllanthus Niruri L.) Secara In Vivo Pada Tikus. J. Bahan Alam Indones. 7, 15-18 (2009).

Sunitha Reddy, M. \& Sowjanya, N. Formulation and in-vitro characterization of solid self nanoemulsifying drug delivery system (S-SNEDDS) of Simvastatin. J. Pharm. Sci. Res. 7, 40-48 (2015).

Zhao, Y. et al. Self-nanoemulsifying Drug Delivery System (SNEDDS) for Oral Delivery of Zedoary Essential Oil: Formulation and Bioavailability Studies. Int. J. Pharm. 383, 170177 (2010). 